\title{
RAJATTOMAAN YHTEISTYÖHÖN
}

$\mathbf{T}$ ekniikka on temmannut mukaansa opetuksen kehittäjät. Audiografiat, sähköpostit, telefaxit ja jopa satelliitit alkavat olla arkipäiväisiä välineitä tiedon välittymisessä. Eri puolilla maailmaa olevat opiskelijat oppivat yhdessä, oppilaitokset tekevät yhteisiä koulutusohjelmia, opiskelijat saavat yksilöllistä ohjausta ja tietoa voi hankkia vaikka kotiinsa kaikista maailman yliopistoista sähköisten medioiden avulla.

Tehokas tiedonsiirto on ollut tähän asti hyödyllisintä tiedemiesten kanssakäymisessä. Sähköpostin välityksellä on ollut mahdollista vaihtaa ajatuksia tutkimuksista, saada välitöntä palautetta omista kirjoituksista ja välittää tietoa tutkimuslaitoksesta toiseen. Tällä hetkellä yliopistojen verkoista on todella helppo saada yhteys kaikkien maanosien yliopistojen kirjastoihin. Niistä voi etsiä hetkessä hakusanojensa avulla tietoa mistä tahansa tutkijoita kiinnostavista aiheista.

$\mathbf{U}$ uden tekniikan käyttöönotto myös opetuksessa on laajentunut muutamassa vuodessa. Kansainvälisellä rahoituksella on ollut käynnissä suuria projekteja, joiden avulla on kehitetty verkostumista tukevaa teknologiaa. Käytössä olevat menetelmät alkavatkin olla teknisesti melko luotettavia ja esimerkiksi kuvien siirto ja videoneuvottelut ovat riittävän hyvälaatuisia ja hinnoiltaan siedettäviä.

Tekniset ongelmat tulevat enää yleensä esille erilaisissa demonstraatiotilanteissa, joissa väliaikaisratkaisujen avulla pyritään osoittamaan uusien viestimien käyttökelpoisuutta. Esimerkiksi Helsingin yliopistossa järjestetyssä uusien opetusmahdollisuuksien esittelyssä vain kaksi esittelyä kymmenestä kärsi teknisistä ongelmista.
Uuden teknologian innokkaimmat kehittäjät ovat useimmiten miehiä. Esimerkiksi edellä mainitussa Helsingin yliopiston tilaisuudessa oli vain yksi nainen yli kymmenen miehen joukossa kertomassa tekniikan luomista opetuksen uusita mahdollisuuksista. Miesten aktivoitumisen etuna on ollut se, että on saatu uusia henkilöitä kiinnostumaan opetuksesta. Ongelmana on se, että opettamisen kehittämisestä on tehty insinöörimäistä: mieluummin tekniikka- kuin oppimiskeskeistä.

Toinen havainto tämän hetkisestä tilanteesta on se, että oppilaitoksissa etäopetuksen kehittäjät matkustavat eniten tätä nykyään. Yhteisten projektien käynnistäminen, niiden suunnittelu ja arviointi ovat osoittautuneet erityisesti matkanjärjestäjille kultasuoneksi. Uudet viestintävälineet eivät ole ainakaan vähentäneet ihmisten tapaamisen tarvetta tai edes kehittäjät eivät osaa käyttää tekniikkaa tässä suhteessa hyväkseen.

$\mathbf{O}$ petusmenetelmien ja oppimateriaalin kehittäminen ei ole pysynyt tekniikan kehittymisen vauhdissa. tähän asti ollaan oltu melko tekniikkakeskeisiä ja uusia medioita on pyritty käyttämään vain perinteisten opetusmenetelmien tavoin tai niitä tukien. Kuitenkin esimerkiksi luennon pito puhelimien välityksellä on erittäin vaativaa ja se edellyttää suurta valmistelua esimerkiksi ennakko- ja muun kurssimateriaalien ja välitehtävien suhteen.

Painopiste on ollut siinä vanhassa oppimisnäkemyksessä, jonka mukaan koulutuksessa olisi riittävän tehokas tiedonsiirto. Tällöin ei ole kannettu paljoakaan huolta opiskelijoiden erilaisista oppimisvalmiuksista. 
Tarvittaisiinkin runsaasti tutkimusta siitä, miten oppiminen tapahtuu ja miten uusilla tiedonsiirtomenetelmillä sitä voitaisiin tukea. Tavoitteena tulisi olla oman didaktiikan kehittäminen esimerkiksi sähköpostin avulla tai puhelimella tapahtuvaa opetusta varten.

Tarvitaan paljon tutkimusta myös siitä, miten tulisi toimia tilanteessa, jossa tiedon saanti jokaisen halukkaan käyttöön on ratkaisevasti helpottunut. Tietohälyn määrän kasvaessa olisi opetuksessa pystyttävä kehittämään kognitiivisia valmiuksia ymmärtämään ja käyttämään tietoa. Eri aloilla toimivien ihmisten ammatillisen kehittymisen kannalta ei pullon kaulana olekaan enää saatavilla olevan tiedon määrä vaan sen käyttöönotto ja olennaisen tiedon erottaminen epäolennaisesta.

$\mathbf{T}$ ässä Aikuiskasvatus-lehden teemanumerossa esitellään erilaisia yhteistyömuotoja. Osittain uuden teknologian, osittain työelämän muuttuvien vaatimusten takia yhteistyön määrä yksilöiden, työryhmien ja työyhteisöjen välillä on olennaisesti lisääntymässä. Mäkelä kirjoittaa artikkelissaan verkostokulttuurista ja -yhteiskunnasta, joka tuo käsitteet vuorovaikutusyhteiskunnasta ja työelämää kuvattaessa etä-, jousto- tai tietotyöstä.

Yhteiskunnan tasolla suuria muutoksia on jo tapahtumassa siinä, että työnteko ei ole sidok- sissa enää mihinkään tiettyyn paikkaan tai aikaan. Myös opiskelu on pääsemässä irti opettaja-, luokka- ja oppikirjasidonnaisuudestaan. Esimerkiksi Kaupin ja Tellan kirjoitukset antavat jo konkreettisia esimerkkejä siitä, miten opiskelijat voivat tehokkaasti hankkia tietoja sähköisten viestimien avulla ja miten oppilaitosten yhteistyön avulla voidaan verkostua.

Euroopassa on jo lukuisia oppilaitosverkostoja, joissa tiedonsiirtoa voidaan edistää yhteisten koulutusohjelmien ja opiskelija- ja opettajavaihtojen avulla. Näistäkin on lehdessämme muutama esimerkki. Yhteisten koulutusohjelmien luomisessa tekniset alat ovat olleet uranuurtajia, mutta muillakin sektoreilla on jo päästy hyvään alkuun.

Verkostuminen on avainsana myös organisaatioiden sisällä. Esimerkkeinä tässä lehdessä ovat kirjoitukset tiimiverkko-organisaatiosta ja kokemukset itseohjautuvista tiimeistä.

$\mathbf{T}$ ässä lehdessä kirjoitukset ovat lähes poikkeuksetta kuvauksia verkostumisen myönteisistä vaikutuksista yhteiskunnille, työyhteisöille ja yksilöille. Tämä on normaalia uusia menetelmiä kehitettäessä. Ei tarvinne olla kuitenkaan suuri ennustaja, jos arvailee, että viiden vuoden kuluttua vastaavassa teemanumerossa tuodaan esille nyt esiteltyjen menetelmien ongelmia ja vaihtoehtoja niille. 